\title{
Clinical and Ambulatory Blood Pressure Monitoring in Subjects with Stent Implanted Aortic Coarctation
}

\section{Stent İmplate Edilmiş Aort Koarktasyonlu Hastalarda Klinik ve Ambulatuar Kan Basıncı İzlemi}

\author{
Nurdan $\operatorname{Erol}^{1 *}$ \\ ${ }^{1}$ SBU Zeynep Kamil Gynecology and Children Diseases Education and Research Hospital, Istanbul, Turkey \\ e-mail: nurdaneroltr61@gmail.com \\ ORCID: 0000-0002-9650-2077
}

*Sorumlu Yazar / Corresponding Author: Sorumlu Yazar: Nurdan Erol ${ }^{1}$

Gönderim Tarihi / Received: 19.01.2020

Kabul Tarihi / Accepted: 07.04.2020 DOI: $10.34087 /$ cbusbed.677143

Giriş ve Amaç: Bu çalışmada başarılı stent implantasyonu yapılmış aort koarktasyonu olan olgularda klinik ve ambulatuvar kan basıncı monitorizasyonu ile devam eden sistemik hipertansiyonu araştırmak amaçlandı.

Gereç ve Yöntemler: Çalışmaya stent implantasyonunun üzerinden en az 6 ay olmak üzere maksimum 3 yıl geçmiş olan aort koarktasyonlu 31 olgu dahil edildi. Olgulara ait demografik, koarktasyonlarına ve stent implantasyonuna ait özellikler, ekokardiyografik bulgular retrospektif olarak incelendi. Çalışma sırasında kan basıncı klasik yöntem ve 24 saatlik ambulatuvar kan basıncı monitorizasyonu ile incelendi. Ekokardiyografileri yapıldı.

Bulgular: Olguların 22'si erkek, 9'u kadındı. Yaş ortalaması 14,50 \pm 6,56 yıl idi. Ortalama vücut kitle indeksi 18,61 \pm 4,02 bulundu. Olguların 16'sı nativ koarktasyon olgusu iken, diğerleri rekoarktasyon olguları idi. Stent implantasyonu işleminin kan basıncı, ekokardiyografik ve anjiyokardiyografik gradiyentler üzerindeki etkinliği istatistiksel olarak anlamlı bulundu. 11 olgu çalışma sırasında antihipertansif ilaç kullanıyordu. 6 normotansif olguda ambulatuvar kan basıncı izleminde hipertansiyon saptand. Total bu 17 olgu hipertansif grup, diğerleri normotansif olarak kabul edildi. Hipertansif ve normotansif grup arasında; İşlem öncesi ve sonrası demografik parametreler, koarktasyon tipi ve çapı, stent tipi ve boyutu, ekokardiyografik ve kateter gradiyentlerinde istatistiksel olarak anlamlı fark yoktu.

Sonuç: Optimal tedaviye rağmen, deneklerin önemli bir bölümünde hipertansiyon devam etmekteydi. Bazı normotansif deneklerde ambulatuvar kan basıncı takibi ile hipertansiyon saptandı. Çalışma, klinik kan basıncı izlemenin sadece hipertansiyonu belirlemek için yeterli olmadığını göstermiştir. Stent implante edilmiş aort koarkatsyonlu olgularda kan basıncı takibinde belirli aralıklarla ambulatuvar kan basıncı ölçümü faydalı olacağı saptanmiştır.

Anahtar Kelimeler: Aort koarktasyonu, stent implantasyonu, hipertansiyon, ambulatuvar kan basincı monitorizasyonu.

\footnotetext{
Abstract

Objective: This study aimed to investigate the frequency of systemic hypertension by clinical and ambulatory blood pressure monitoring in subjects with stent implanted aortic coarctation.

Materials and Methods: The study included in 31 subjects with stent implanted aortic coarctation before at least 6 months to 3 years. Related features of subjectes, procedure, echocardiografhic findings were evaluated retrospectively. Blood pressure were examined by classical method and 24-hour ambulatory blood pressure monitoring.

Results: 22 of subjects were male and 9 were female. Mean age was $14.50 \pm 6.56$ years. The mean body mass index was found to be $18.61 \pm 4,02.16$ of them had native coarctation, others had recoarctation. The efficiency of procedure on blood pressure, echocardiographic and angiocardiographic gradients was found to be statistically significant. 11 subjects were using antihypertensive drug. Six normotensive subjects had hypertensive in ambulatory blood pressure monitoring.17 subject were considered hypertensive group, others normotensive. There was not statistically
} 
significant difference between hypertensive group and normotensive group in demographic paramaters, coarctation type and diameter, the stent type and size, echocardiographic and catheter gradients before and after the procedure.

Conclusion: Despite optimal treatment, hypertension persists in an important part of the subjects. Some normotensive subjects had hypertensive with ambulatory blood pressure monitoring. The study showed that clinical blood pressure monitoring does not sufficient to determined hypertension alone. Ambulatory blood pressure measurement with regular intervals will be beneficial in the follow-up of these subjects for hypertension.

Key Words: Aortic coarctation, stent implantation, hypertension, ambulatory blood pressure monitoring.

\section{Introduction}

Aortic coarctation is obstruction in any part of the descendent aorta generally at a point distal to the left subclavian artery. [1-4] Although The simplicity of its anatomical appearance, It is a rather complex pathology in terms of its clinical presentation, treatment options and long-term prognosis.

Crafoord and Nylin performed the first successful surgical treatment of coarctation in 1944 [2-4, 6], then balloon angioplasty (1982) and stent implantation (1991) were added.[1-4]. Despite all these different treatment options, the efficiency of these treatments in eliminating coarctation, the long-term prognosis of the disease is not benign.[5] Systemic hypertension is one of the most important factors which worsens the prognosis.

Despite successful coarctation treatment it is known that hypertension at rest, hypertension during daily acitivities and/or exercise-induced hypertension persists in many cases.[7,8] The cause of hypertension in patients with coarctation has not been fully elucidated. Factors including residual coarctation, scar tissue, graft interposition, increased aortic stiffness, decreased compliance, disrupted arterial reactivity, abnormal pulsed wave velocity, decreased baroreceptor reflex function and disrupted anatomy of the aortic arch have been implicated.[7,8]

In this study we aimed to investigate the frequency of hypertension with clinical examination (arterial blood pressure measurement) and additionally with ambulatory blood pressure monitoring in subjects with stent implented aortic coarctation who had no rezidual or recurrent coarctation.

\section{Material ve Metods}

The study included in 31 subjects with stent implanted aortic coarctation. The stent implantation procedure had performed at least 6 months to 3 years in all subject. In pediatric Cardiology policlinic, the subjects was included who regularly follow-up stent implented aortic coarctation and who gave consent for the study. The study group was composed of children above 5 years of age, adolescents and adults. Retrospective evaluation of the demographic characteristics, features related to stent implantation procedure, examination findings and echocardiography findings before procedure was examined retrospectively.

Stent implantation was performed successful and optimal for all patients. After the procedure the subjects were followed up regularly by echocardiography and blood pressure measurements in all four extremities at 1, 3, 6 and 12 months. The antihypertensive drugs used were learned from follow-up records, from the subjects themselves or from the families.

At the study time, after general physical examination and a 5-minutes rest, blood pressure measurements were done in all four extremities seperately 3 times using Marquette Type 555 (Hellige Medical Systems) Doppler blood pressure monitor in the supine position. The study was based on the mean value of the measurements. The difference between the systolic blood pressures measured in the right arm and right leg was recorded. Blood pressure values were classified accoring to age, gender and height percentile tables stated in the 4th report of National High Blood Pressure Education Program Working Group on High Blood Pressure in Children and Adolescents. A value of 95 th percentile and above was considered to be hypertension.[10] The study was performed without discontinuing the antihypertensive drugs used by the subjects to eliminate the disadvantages. Echocardiography at baseline and in follow-up vizits was performed using (Vivid 3 Pro, GE Medical Systems, Vingmed Ultrasound AS, N-3190 Horten, Norway). Coarctation region in the descendent aorta and gradients in the stent region were recorded by Doppler. Additional abnormalities accompanying coarctation were determined by echocardiography.

A one-day Holter monitoring was performed in the subjects using an ambulatory blood pressure Holter device (Tracker NIBP2, Del Mar Reynolds Medical) .The cuff was placed on the right arms of the subjects. The subjects were told to continue their daily acitivities during the procedure avoiding intense effort. The obtained ambulatory blood pressure values were evaluated according to the normal values of ambulatory blood pressure in healthy white children reported by Wühl et al.[11] Subjects who were found to have a value above the 95th percentile were considered as the hypertensive group, others as the normotensive group. The subjects who were diagnosed clinically as hypertension and who were receiving antihypertensive treatment were considered in the hypertensive group. Consent was obtained from the local ethics committee, from the adult patients and from the families of pediatric patients for the study.

Analysis of the data was done using SPSS 16 (Statistical Package of the Social Sciences, SPSS Inc. Chicago, Illinois) statistical package program. A p less than 0.05 was considered statistically significant in all analyses.

\section{Results}

$21(71 \%)$ of 31 subjects were male and $9(29 \%)$ were female. At the time of the study, the mean age of the 
subjects was found to be $14,50 \pm 6,56 \quad(5-37$, median:13,48) and the mean body mass index was found to be $18,61 \pm 4,02(12,84-25,71$, median 17,51$)$. 16 $(51,6 \%)$ of the subjects had native coarctation and 15 $(48,4 \%)$ had recoarctation. $11(35,5 \%)$ of these 15 subjects had recoarctation after balloon and $4(12,9 \%)$ had recoarctation after surgery. $28(90,3 \%)$ of the subjects had discrete lesion and $3(9,7 \%)$ had tubular lesion. (Table 1).

Bare-metal stent was used in 23 subjects and covered stent was used in 8 subjects. The optimal criterion for success was considered as a "peak to peak" systolic pressure gradient lower than $10 \mathrm{mmHg}$ after stent implentation. Echocardiographic and catheter coarctation gradient before and after stent implantation was showed at Table 2.

Table1. Characteristics of coarctation in all patients in the study group

\begin{tabular}{|l|l|r|r|}
\hline \multicolumn{2}{|c|}{ Manifestations } & Number & \% \\
\hline \multirow{3}{*}{ Characteristic of coarctation } & Native & 16 & 51,6 \\
\cline { 2 - 4 } & Recoarctation after balloon & 11 & 35,5 \\
\cline { 2 - 4 } & Recoarctation after surgery & 4 & 12,9 \\
\hline \multirow{2}{*}{ Morphology of coarctation } & Discrete & 28 & 90,3 \\
\cline { 2 - 4 } & Tubular & 3 & 9,7 \\
\hline \multirow{3}{*}{ Characteristic } & Isthmus hypoplasia & 1 & 3,1 \\
\cline { 2 - 4 } & Association of patent ductus arteriosus & 3 & 9,4 \\
\cline { 2 - 4 } & Subatretic & 2 & 6,2 \\
\hline
\end{tabular}

Table 2. Comparison of ascendent aorta and descendent systolic pressures gradients obtained from echocardiography and catheter before and after stent implantation

\begin{tabular}{|l|c|c|c|c|}
\hline \multicolumn{1}{|c|}{\begin{tabular}{c}
\multicolumn{1}{c|}{$\begin{array}{c}\text { Pressures and gradients } \\
\text { (mmHg) }\end{array}$} \\
\hline Echocardiographic gradient
\end{tabular}} & $\begin{array}{c}\text { Before the } \\
\text { procedure } \\
(\mathbf{n : 3 1 )}\end{array}$ & $\begin{array}{c}\text { After the } \\
\text { procedure } \\
(\mathbf{n : 3 1})\end{array}$ & $\mathbf{t}^{*}$ & $\mathbf{p}^{* * *}$ \\
\hline $\begin{array}{l}\text { Ascendent aorta sysytolic blood } \\
\text { Pressure }\end{array}$ & $59,4 \pm 16,9$ & $28,3 \pm 12,0$ & 8,53 & 0,00001 \\
\hline $\begin{array}{l}\text { Ascendent aorta diastolic blood } \\
\text { Pressure }\end{array}$ & $73,4 \pm 20,5$ & $136,9 \pm 15,2$ & 3.73 & 0,001 \\
\hline $\begin{array}{l}\text { Ascendent aorta-descendent aorta } \\
\text { pressure gradient }\end{array}$ & $42,4 \pm 15,9$ & $64,4 \pm 15,0$ & 2,31 & 0,0275 \\
\hline
\end{tabular}

* Paired sample t test, $* * \mathrm{p}<0.05$ significant

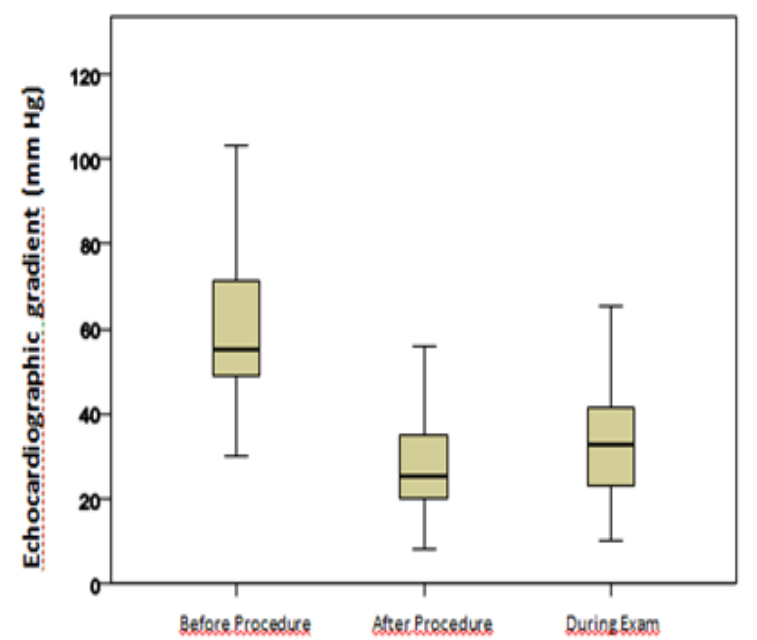

Figure 1. The pressures difference between peak -topeak gradient with CW Doppler in coarctation region obtained by echocardiography of 31 stent-implanted subjects are shown at first box diagram, one day after stent implantation at second box diagram and during the study at third box diagram at the figure. 
The echocardiography coarctation gradients on the first day, at the first month and 6th month after stent implantation was observed that a significant decrease compared to the values measured before precedure, but no significant increase occured in terms of gradient in the follow-up (Figure 1).

While the mean echocardiographic gradient before the procedure was found to be $59,4 \pm 16,9 \mathrm{~mm} \mathrm{Hg}$ (30-103, median $55 \mathrm{~mm} \mathrm{Hg}$ ), this value decreased to $28,3 \pm 12,0$ (8-40, median $25 \mathrm{~mm} \mathrm{Hg}$ ) $\mathrm{mm} \mathrm{Hg}$ after the procedure (p: 0,0001) (Figure 1). However, although echocardiographic gradient increased to $32,4 \pm 13$ (10-45, median $32 \mathrm{~mm} \mathrm{Hg}$ ) $\mathrm{mm} \mathrm{Hg}$ during the study, this was not found to be statistically significant (p: 0.052). In addition, typical diastolic flow pattern specific for coarctation could not be obtained in any subject. Therefore, systemic hypertension which can be found in these subjects is not related to residual or recurrent coarctation.

Upper and lower extremity arterial pressures obtained noninvasively with a blood pressure monitor before stent implantation and one day after stent implantation and comparison of their differences are summarized in Table 3.

Table 3. Comparison of upper-lower extremity arterial pressures measured non-invasively with a blood pressure monitor before and after stent implantation and their differences

\begin{tabular}{|l|r|r|r|r|}
\hline \multicolumn{1}{|c|}{$\begin{array}{c}\text { Pressures and gradients } \\
\text { (mmHg) }\end{array}$} & $\begin{array}{c}\text { Before the procedure } \\
(\mathbf{n : 3 1 )}\end{array}$ & $\begin{array}{c}\text { After the procedure } \\
(\mathbf{n : 3 1 )}\end{array}$ & $\mathbf{t}^{*}$ & $\mathbf{p}^{* *}$ \\
\hline Right arm systolic blood pressure & $136,2 \pm 18,0$ & $125,2 \pm 17,0$ & 3,38 & 0,0020 \\
\hline Right arm diastolic blood pressure & $73,4 \pm 22,2$ & $64, \pm 415,0$ & 2,31 & 0,0275 \\
\hline $\begin{array}{l}\text { Difference between upper and lower } \\
\text { extremity systolic pressures }\end{array}$ & $35,6 \pm 20,1$ & $6,7 \pm 16,4$ & 6,89 & $<0,00001$ \\
\hline
\end{tabular}

* Paired sample t test, $* * p<0.05$ significant

Mean right arm systolic blood pressure measured after stent implantation decreased significantly (p: 0,0020) This result shows that stent implantation procedure has a positive effect on systolic blood pressure. The right arm diastolic blood pressure showed a statistically significant difference between the value before stent implantation and the value after stent implantation (p: 0,0275). The mean difference between the upper and lower extremity systolic blood pressures was also found to be statistically significant to a considerable extent (p: 0,00001).

The subjects were evaluated clinically with manuel and ambulatory blood pressure monitoring after a mean period of $14.2 \pm 9.1$ (6-30, mediyan 13,6) months after procedure.

11 of 31 subjects who were included in the study were using antihypertensive drug. Nine subjects were using beta-blocker, one subject was using angiotensin converting emzyme inhibitor and one subject was using beta blocker and angiotensing converting enzyme inhibitor.

It was observed that blood pressures in three who were using antihypertensive drugs were completely under control in the clinical follow-up and ambulatory Holter monitoring.

Five subjects had hypertensive ambulatory Holter values and three subjects had prehypertensive values (90-95th percentile). Despite the antihypertensive treatment, the blood pressure of these subjects were uncontrolled.

With clinical arterial blood pressure measurements, hypertension was found in 5 of 20 subjects who were not using antihypertensive drugs. In three, hypertension was also found with ambulatory blood pressure measurements. the other 2 subjects were normal in ambulatory blood pressure measurements, they were considered to have white coat hypertension.
Again, three subjects were found to be hypertensive with Holter monitoring, although their clinical systolic blood pressure measurements were found to be within normal limits. These were considered as masked hypertension. Thus, the actual frequency of hypertension was 6 of 20 among the subjects who were not using antihypertensive drugs. Four prehypertensive subjects with normal clinical systolic blood pressure values and non-hypertensive values in Holter monitoring which needed close followup (90-95th percentile) were found in this group.

Parametric and nonparametric values were compared between 14 normotensive subjects and 17 hypertensive subjects. (Table 4).

No statistically significant difference was found between the two grups in terms of age, weight, body mass index, coarctation diameter, echocardiographic and angiocardiografic gradient before and after the procedure, stent lentghs used ( $\mathrm{p}<0.05)$.

Again, no statistically significant difference was found between the two grups in terms of gender, coarctation type (native, recoarctation), stent type used (covered, bared), age at the time of first intervention below or above 10 years. ( $p$ above than 0,05 ).

\section{Discussion}

Aortic coarctation constitutes $4-8 \%$ of congenital cardiac diseases [1-4]. Life expectancy was found to be decreased in patients with aortic coarctation who had been treated compared to healthy normal adults [1-4,1214].

The main problems observed in these patients include recoarctation, aortic aneurism or aortic dissection, biküspid related complications, endocarditis, early coronary atherosclerosis, cerebrovascular events and systemic hypertension. 
Table 4. Comparison of parametric characteristics of normotensive and hypertensive subjects

\begin{tabular}{|c|c|c|c|c|}
\hline & Subjects by Bloo & Pressure Status & & \\
\hline & $\begin{array}{l}\text { Normotensive } \\
\quad(\mathrm{n}: 14)\end{array}$ & $\begin{array}{l}\text { Hypertensive } \\
\quad(\mathrm{n}: 17)\end{array}$ & $\mathrm{t}$ & $\mathrm{p}$ \\
\hline Body mass index & $17,8 \pm 4,049$ & $19,28 \pm 4,01$ & $-1,01$ & 0,321 \\
\hline Weight (kg) & $43,32 \pm 19,69$ & $48,9 \pm 119,06$ & $-0,80$ & 0,430 \\
\hline Height (meter) & $1,51 \pm 0,22$ & $1,5 \pm 50,21$ & $-0,51$ & 0,613 \\
\hline The age at the first procedure (years) & $11,54 \pm 9,27$ & $10,11 \pm 5,59$ & 0,51 & 0,609 \\
\hline Echocardiographic gradient before the procedure (mmHg) & $59,00 \pm 19,93$ & $60,94 \pm 14,11$ & $-0,31$ & 0,754 \\
\hline Catheter gradient before the procedure $(\mathrm{mmHg})$ & $43,00 \pm 14,33$ & $43,35 \pm 16,44$ & $-0,06$ & 0,950 \\
\hline Catheter gradient after the procedure $(\mathrm{mmHg})$ & $2,00 \pm 2,88$ & $3,4 \pm 13,89$ & $-1,12$ & 0,269 \\
\hline $\begin{array}{l}\text { Ascendent aorta systolic blood pressure before the procedure } \\
(\mathrm{mmHg})\end{array}$ & $148,50 \pm 19,46$ & $152,7 \pm 620,59$ & $-0,58$ & 0,561 \\
\hline $\begin{array}{l}\text { Ascendent aorta systolic blood pressure after the procedure } \\
(\mathrm{mmHg})\end{array}$ & $134,79 \pm 15,90$ & $137,59 \pm 14,30$ & $-0,51$ & 0,610 \\
\hline Stent lenght $(\mathrm{mmHg})$ & $31,57 \pm 6,89$ & $35,24 \pm 8,72$ & $-1,27$ & 0,212 \\
\hline Coarctation diameter $(\mathrm{mmHg})$ & $6,39 \pm 3,08$ & $7,68 \pm 2,91$ & $-1,20$ & 0,240 \\
\hline
\end{tabular}

Persistent systemic hypertension is the major factor contributing to increase in the cardiovascular risk and is found in $17-57 \%$ of the patients who have been treated for coarctation. [7,9]

The effects of surgical treatment, balloon angioplasty and stent implantation performed for treatment of aortic coarctation on hypertension and in cases of exercise hypertension have been the subject of many studies and investigated with various aspects [9,15-30].

Harrison et al. reported systemic hypertension regressed in 19 of 26 subjects in whom stent implantation was performed and Magee et al reported the need for drug treatment was eliminated in 9 of 17 subjects after stent implantation [32,33] Carr complied and compared the articles related to invasive and surgical treatments in 2006 [34]. In these studies, it was found that the mean rate of hypertension was $61 \%(18-88 \%)$ in the invasive group and $64 \%(13-76 \%)$ in the surgery group. Thus, the rate of hypertension was found to be similar in these groups [34].

The effects of stent implantation in lowering arterial blood pressure have been discussed in many aspects in different studies. Hamdan et al. found that the systolic blood pressure decreased from $136 \pm 21 \mathrm{~mm} \mathrm{Hg}$ to 122 $\pm 19 \mathrm{~mm} \mathrm{Hg}$ in 31 subjects with coarctation (13 of them were native) with a mean age of 16 in whom they performed stent implantation in 2001.[35] While hypertension was present in $71 \%$ of these subjects and a history of drug usage was present in $42 \%$ before the procedure, hypertension and drug usage persisted in only $26 \%$ after the procedure [35]. Tzifa et al. reported antihypertensive treatment was discontinued or the drug dose was decreased in the follow-up after the procedure in $43 \%$ of 33 subjects with a mean age of 28 (8-65 years) in whom they performed covered stent implantation.[36] Musto et al. followed up 21 subjects with an age of 1273 years in whom 8 balloon angioplasty and 13 stent implantation were performed for a mean period of 50,6 months (6-82 months) in the study they performed in 2008. They demostrated the effect of invasive interventions in lowering blood pressure by finding that the systolic blood pressure decreased from $157 \pm 16$ $\mathrm{mmHg}$ to $123 \pm 13 \mathrm{~mm} \mathrm{Hg}$ after the first month in the follow-up in these subjects.[37] However, they observed that hypertension persisted in $33 \%$ of the subjects in the follow-up.[37]

When we examined the echocardiographic and angiocardiographic gradient values in our study group before the procedure, after the procedure and during the study, we observed that the interventions were successful. When the right arm systolic and diastolic blood pressure values and the difference between the right arm-right leg blood pressure were examined before the procedure, after the procedure and during the study, the efficiency of the interventions performed was demostrated.

In our study, it was observed that $17(54,8 \%)$ of 31 subjects were hypertensive and $14(45,2 \%)$ were normotensive. Although this rate seems to be high, it is compatible with the findings in the literature. [7,8,14,38] There was a significant difference between normotensive and hypertensive group in terms of mean systolic blood 
pressure, nocturnal and daytime systolic blood pressure and systolic blood pressure load. However, there was no statistically significant difference between these two groups in terms of age, gender, body weight and body mass index, coarctation type (native or recoarctation) and stent type used. Again, there was no statistically significant difference between these two groups in terms of coarctation diameter, echocardiographic and catheter gradients before and after the procedure, ascendent aorta pressures before and after the procedure and stent lenght used $(\mathrm{p}<0,05)$

It is considered that a diagnosis of hypertension based on ambulatory blood pressure measurements in adults and children gives more valuable results compared to clinical blood pressure measurement.[39-46] In our study, white coat hypertension was found in $2(6,5 \%)$ of 31 subjects. Ambulatory blood pressure monitoring is reported to be the most reliable method to differentiate white coat hypertension from actual hypertension. [47,48] Observation of white coat hypertension also in our study suggests that ambulatory blood pressure monitoring may be appropriate in the diagnosis and follow-up of aortic coarctation cases to avoid unnecessary antihypertensive drug usage. [47,48]

On the other hand, diagnosing masked hypertension cases is important, since these individuals have been reported to have an equal risk as individuals with persistent hypertension in different studies.[47,48] In our study, masked hypertension was found in $3(9,7 \%)$ of 31 subjects. Because of the possibility of skipping masked hypertension with only clinical measurement, ambulatory blood pressure measurement in these subjects is important.[47,48]

Another finding of us which showed the importance of ambulatory blood pressure measurement was the fact that 5 subjects still had hypertensive blood pressure values in ambulatory blood pressure Holter monitoring, although they were using antihypertensive drugs. 3 subjects who were using antihypertensive drugs had prehypertensive values (between the 90th and 95th percentiles of blood pressure measurement) in ambulatory Holter monitoring. The relation between prehypertension and persistent hypertension was examined in various studies and the importance of follow-up in these subjects was emphasized.[39] Considering the risk of conversion of prehypertension to persistent hypertension in the followup, long-term follow-up of these subjects and examination in terms of end-organ demage are important.[39]

While 20 of 31 subjects in our study group were not using antihypertensive medication, 14 of 20 subjects who had normotensive findings in ambulatory, others had not. 5 of 11 subjects in the hypertensive drug using group were hypertensive at ambulatory blood pressure measurement, despite therapy. After diagnosing hypertension with ambulatory blood pressure measurement, it was revised drug therapy.

The cause of the recurrence of hypertension in cases with treated coarctation is unknown. It is thought that administering treatment at an early age helps prevent hypertension based on the observation that the rate of hypertension in cases that were surgically treated before the age of 1 was $10 \%$, while the rate was $33 \%$ on those that were treated after the age of 14 (13). However, although hypertension can be prevented with treatment, it was observed that it recurred during the follow-up of the patients (14), which may have been caused by the late administration of treatment and native coarctation, which was observed in 16 of the patients $(51 \%)$ in our study group. Potential causes of post-treatment hypertension are thought to be hyper activation of the reninangiotensin system, baroreflex failure, reactivity dysfunctions of the arteries, which include the increase in resistance of small arteries, the decrease in reactivity of medium-large arteries and the functional and structural damage that leads to increased stiffness in the arteries (7). There are different perspectives on the impact of hyper activation of the renin-angiotensin system and baroreflex failure on the recurrence of hypertension in such cases. Regarding vascular reactivity dysfunction, it was observed that although the arteries recovered their elasticity after the coarctation treatment, vascular reactivity dysfunction continued, indicating that it starts at an early age and does not respond to treatment (7), suggesting that it might be a cause of recurring hypertension. However, further research on the cause of recurring hypertension post-coarctation treatment is required for a better understanding of the condition.

\section{Conclusion}

Stent implantation is an efficient method in treatment of coarctation. With this treatment systolic and diastolic arterial blood pressures decrease significantly and systemic hypertension is affected positively. However, hypertension persists in some of the patients even though sufficient dilatation and optimal decrease in gradients. In some of these subjects, hypertension can not be demostrated with classical measurements and can only diagnosed in ambulatory blood pressure monitoring.

It is not possible to predict which subjects will have persistent hypertension after interventional treatment. Therefore, close clinical follow-up is necessary after intervention. In addition to standard arterial blood pressure measurement, ambulatory blood pressure monitoring should be performed and repeated periodically. In this way, the diagnoses of prehypertension, masked hypertension and white coat hyperension can be made accurately. Ambulatory blood pressure monitoring is also important for evaluation of the efficiency of antihypertensive drug treatment and for tailoring treatment.

\section{Acknowledgement}

Special thanks to Prof. Dr. Ahmet Çelebi and Prof. Dr. Abdullah Erdem for their contributions for my fellowship education and in the preparation of my thesis. 


\section{References}

1. Beekman, HR, Coartation of the aorta, In: Allen HD, Driscoll, DJ, Shaddy, RE, Feltes, TF, editors. Moss and Adams' heart disease in infants, children, and adolescents including the fetus and young adult 7th ed. India: Lippincott Williams and Wilkins, 2008, 937-1005.

2. Hoschtitzky, JA, Anderson, RH, Elliott, MJ, Aortic coarctation and interrupted aortic arch, In: Anderson, RH, Baker, EJ, Penny, DJ Redington, AN, Rigby, ML, Wernovsky, G, editors. Paediatric Cardiology, 3rd ed. China: Churchill Livingston, 2010, 945-966.

3. Keane, JF, Fyler, DC, Coarctation of the aorta, In: Keane JF, Lock JE, Fyler DC, editors, Nadas' Pediatric Cardiology, 2nd ed, Philedelphia, Pa: Saunders Elsevier, 2006, 627-644.

4. Park, MK, Pediatric Cardiology for Practioners, 5th ed, Phledelphia PA: Mosby Elsevier, 2008, 205-213.

5. Campell, M, Guordano, U, Giannico, S, Turchetta, A, Natural history of aortic coarctation of the aorta, British Heart Journal, 1970, 32 , 633-640

6. Crafoord, C, Nylin, G, Congenital coarctation of the aorta and its surgical treatment, J Thorac Surg, 1945, 14, 347-361.

7. Divitiis de M, Rubba, P, Calabro, R, Arterial hypertension and cardiovascular prognosis after successful repair of aortic coarctation: A clinical model for the study of vascular faunction, Nutrition Metabolism \& Cardivascular Diseases, 2005, 15, 382-394.

8. Hager, A, Kanz, S, Kaemmerer, H, et al, Coarctation long term assessment (COALA): significance of arterial hypertension in a cohort of 404 patients up to 27 years after surgical repair of isolated coarctation of the aorta, even in the absence of restenosis and prosthetic material, The Journal of Thoracic and Cardiovascular Surgery, 2007, 134, 738-745.

9. Vriend, JWJ, Mulder, BJM, Late complications in patients after repair of aortic coartation: implications for management, Internaional Journal of Cardiology, 2005, 101, 399-406.

10. National High Blood Pressure Education Program Working Group on high blood pressure in children and adolescents, The fourth report onthe diagnosis, evalutation, and treatment of high blood pressure in children and adolescents, Pediatrics, 2004, 114, 555-576.

11. Wühl, E, Witte, K, Soergel, M et al, Distrubution of 24-h ambulatory blood pressure in children: normalized reference values and role of body dimension, Journal of Hypertension, 2002, 20, 1995-2007.

12. Koller, M, Rothlin, M, Senning, A, Coarctation of the aorta: review of 362 operated patients, Long-term follow-up and assesment of prognostic variables, European Heart Journal, 1987, 8, 670-679.

13. Cohen, M, Fuster, V, Steele, PM et al, Coarctation of the aorta, long term follow-up and prediction of outcome after surgical correction, Circulation, 1989, 80, 840-845

14. Clarkson, PM, Nicholson, MR, Barrat-Boyes, BG et al, Results afte repair of coarctation of the aorta beyond infants: a 10 to 28 years follow-up with particular reference to late systemic hypertension, American Journal of Cardiology, 1983, 81, 1541-1548.

15. Leandro, J, Smallhorn, JF, Benson, L et al, Ambulatory blood pressure monitoring and left ventricular mass and function after successful surgical repair of coarctation of the aorta, Journal of the American College of Cardiology, 1992, 20, 197-204.

16. Divitiis de M, Pilla, C, Kattenhorn, M et al, Ambulatory blood pessure, left ventricular mass and conduit artery function late after successful repair of coarctation of the aorta, Journal of the American College of Cardiology, 2003, 41, 2259-2265.

17. Gidding, SS, Roccini, AP, Moorehead, C et al, Increased forearm vascular reaktivity in patients with hypertension after repair of coarctation, Circulation, 1985, 71, 495-499.

18. Hashemzadeh, K, Hashemzadeh, S, Kakaei, F, Repair of aortic coarctation in adults: the fate of hypertension, Asian Cardiovascular and Thoracic Annals, 2008, 16, 11-15.

19. Giordano, U, Giannico, S, Turchetta, A et al. The influence of different surgical procedures on hipertension after repair of coarctation, Cardiology in the Young, 2005, 15, 477-480.

20. Daniells, SR, Repair of coarctation of the aorta and hypertension: Does age matter? The Lancet, 2001, 358, 89.

21. Instebo, A, Norgard, G, Helgheim V et al, Exercise capacity in young adults with hypertension and systolic blood pressure difference between right arm and leg after repair of coarctation of the aorta, European Journal of Applied Physiology, 2004, 93, 116-123.

22. Ruttenberg, HD, Pre and postoperatif exercise testing of the child with coarctation of the aorta, Pediatric Cardiology, 1999, 20, 33-37.
23. Witsenburg, M, Salem, HKT, Bogers, AJJC et al, The balloon angioplasty for aortic recoarctation in children: initial and follow up results and midterm effect on blood pressure. British Heart Journal, 1993;70:170-174

24. Yaveri A, Sezgin A, Mercan Ş, et al. Aort koarktasyon cerrahisi sonrası rekoarktasyon olasılığının değerlendirilmesi, GKDC Dergisi, 1998, 6, 306-309.

25. Mahadevan, VS, Vondermuhll, IF, Mullen, MJ, Endovascular aortic coarctation stenting in adolescents and adults: angiogrphic and hemodynamic outcomes, Catheterization and Cardiovascular Interventions, 2006, 67, 268-275.

26. Vriend, JWJ, Montfrans, GA, Romkes, HH et al, Relation between exercise induced hypertension and sustained hypertension in adult patients after successful repair of aortic coarctation, Journal of Hypertension, 2004, 22, 501-509.

27. Chen, SS, Donald, AE, Storry $\mathrm{C}$ et al, Impact of aortic stenting on peripheral vascular function and daytime systolic blood pressure in adult coarctation, Heart, 2008, 94, 919-924.

28. Bassareo, PP, Maras, AF, Manai, ME et al, The influence of different surgical approachhes on arterial rigidity in children after aortic coarctation repair, Pediatric Cardiology, 2009, 30, 414-418.

29. Johnson, D, Perrault, H, Vobeckyt, SJ et al, Influence of the postoperative period and surgical procedure on ambulatory blood pressure determination of hypertension load after succesful surgical repair of coarctation of the aorta, European Heart Journal, 1998, 19 638-646.

30. Duara, R, Thedore, S, Sarma, PS et al, Correction of coarctation of aorta in adult patients impact of corrective procedure on long term recoarctation and systolic hypertension, The Journal of Thoracic and Cardiovascular Surgery, 2008, 56, 83-86.

31. Freed, MD, Rocchini, A, Rosenthal, A et al, Exercise-induced hypertension after surgical repair of coarctation of the aorta, American Journal of Cardiology, 1979, 43, 253-258.

32. Harrison, DA, Mclaughlin, PR, Lazzam, C et al, Endovascular stents in the management of coarctation of the aorta in tehe adolescentand adult: one year follow-up. Heart, 2001, 85, 561-566.

33. Magee, AG, Brzezinska-Rajszys, G, Qureshi, SA et al, Stent implantation for aortic coarctation and recoarctation, Heart, 1999, 82, 600-606.

34. Carr, JA, The results of catheter based therapy compared with surgical repair of adult aortic coarctation, Journal of the American College of Cardiology, 2006, 47, 1101-1107.

35. Hamdan, MA, Maheshwari, S, Fahey, JT et al, Endovascular stent for coarctation of the aorta: initial results and intermediate term follow up, Journal of the American College of Cardiology, 2001, 38 , 1518-1523.

36. Tzifa, A, Ewert, P, Brezinska-Rajszys, G, Peters, B et al, Covered cheatham platinum stents for aortic coarctation, Journal of the American College of Cardiology, 2006, 47, 1457-1463.

37. Musto, C, Cifarelli, A, Pucci, E et al, Endovasculartreatment of aortic coarctation, Long term effects on hypertension, International Journal of Cardiology, 2008, 130, 420-425.

38. Toro-Salazar, OH, Steinburger, J, Thomas, W et al, Long-term follow-up of patients after coarctation of the aorta repair, American Journal of Cardiology, 2002, 89, 541-547.

39. Urbina, E, Alpert, B, Flynn, J et al, Ambulatory blood pressure monitoring in children and adolescents: Recomendations for standart assessment, A Scientific statement from the American Heart Associatilon Atherosclerosis, Hypertension, and Obesity in Youth Committee of the Council on Cardiovascular Disease in the Young and the Council for High Blood Presure Research, Hypertension 2008, 52, 433-451.

40. Lurbe, E, Redon, J, Ambulatory blood pressure monitoring in children and adolescents: the future, Journal of Hypertension, 2000, $18,1351-1354$

41. Khan, IA, Gajaria, M, Stephens, D et al, Ambulatory blood pressure monitoring in children: a large center's experience Pediatric Nephrology, 2000, 14, 802-805.

42. Flynn, TJ, Differentation between primary and secondary hypertension in children using ambulatory blood pressure monitoring, Pediatrics, 2002,110, 89-93.

43. Graves, JW, Althaf, MM, Utility of ambulatory blood pressure monitoring in children and adolescents, Pediatric Nephrology, 2006 , $21,1640-1652$. 
44. Gimpel, C, Wühl, E, Arbeiter, K et al, Superior consistency of ambulatory blood pressure monitoring in children: implications for clinical trials, Journal of Hypertension, 2009, 27, 1568-1574.

45. Acosta, AA, McNiece, KL, Ambulatory blood pressure monitoring: a versatil tool for evaluating and managing hypertension in children, Journal of Hypertension, 2008, 23, 1399-1408.

46. Alpay, H, Özdemir, N, Wühl, E et al, Ambulatory blood pressure monitoring in healty children with parental hypertension, Journal of Hypertension, 2009, 24, 155-161.

47. Andrade, H, Antonio, N, Rodrigues, D et al, Hipertensao arterial sistemica em idade pediatrica, Revista Portuguesa de Cardiologia, $2010,29,413-432$

48. National High Blood Pressure Education Program Working Group on high blood pressure in children and adolescents, The fourth report onthe diagnosis, evalutation, and treatment of high blood pressure in children and adolescents, Pediatrics, 2004, 114, 555-576.

http://edergi.cbu.edu.tr/ojs/index.php/cbusbed isimli yazarın CBU-SBED başlıklı eseri bu Creative Commons Alıntı-Gayriticari4.0 Uluslararası Lisansı ile lisanslanmıştır.

(c) (i) (8) 